\title{
Můj pohled na život a dílo Vladimíra Helferta
}

\section{Life and Work of Vladimír Helfert From My Point of View}

\author{
Jiři Vysloužil † \\ Ústav hudební vědy FF MU, Brno, CZ
}

\begin{abstract}
The study deals with the founder of musicology in Brno, professor Vladimír Helfert, whose musicological work is valuated against the background of his life. Significant emphasis is laid on a Helfert's conception of a Czech modern music and also on Leoš Janáček. In the text we can find information about musical reflection on Helfert's work. Some parts in the study are dedicated to the musicologists who were devoted to Helfert's heritage (Jiř́ Fukač, Jiří Vysloužil, Rudolf Pečman etc.)
\end{abstract}

\section{Key words}

Vladimír Helfert, Leoš Janáček, Czech music, musicology, Brno, reflection 
Byl jsem požádán vedením Ústavu hudební vědy Filozofické fakulty Masarykovy univerzity, abych při př́ležitosti 70. výročí úmrtí a 130 . výročí narození zakladatele brněnské hudební vědy, profesora Vladimíra Helferta, pojednal o jeho životě a díle. S pohnutím mysli jen tiše vzpomínám na přední znalce jeho odkazu, Rudolfa Pečmana, Ivana Poledňáka a Theodoru Strakovou. Byli hlavními řečníky konference s názvem Vladimír Helfert v českém a evropském kontextu, ${ }^{1}$ kterou k uctění stého výročí Helfertova narození uspořádal v roce 1986 Svaz českých skladatelů a koncertních umělců.

Nemohl jsem se helfertovské konference v roce 1986 účastnit, poněvadž jsem ležel $\mathrm{s}$ vážným onemocněním v nemocnici na Žlutém kopci v Brně. Poslal jsem tedy konferenci krátký pozdrav. Připomněl jsem, kterak se důvěřivý prodavač hudebního nakladatele Oldřicha Pazdírka mně nebál za Protektorátu podstrčit pod pultem několik knih německými nacisty vězněného profesora Vladimíra Helferta. Z nich se stala kniha Česká moderni hudba mou nejmilejší Helfertovou knihou. Četl jsem si v ní, prokousával jsem se jejími Prolegomeny a Doslovem. Stál jsem za ní v „padesátých letech“, když byla označována předáky Svazu československých skladatelů za dekadentní projev měštácké formalistické estetiky, takto ještě v úvodním referátu Jaroslava Jiránka na pražské konferenci o současné české hudební vědě, konané někdy roku 1956, kdy již začaly „ledy tát“, řečeno slovy sovětského spisovatele Ilji Erenburga. Jiránkovu nařčení Helferta jsem čelil s profesorem Janem Rackem přímo na místě, což poznamenalo moji reputaci ve svazu a odtud mělo i zabránit mému návrhu na přijetí brněnské hudebně vědné komise do hudebně vědecké sekce skladatelského svazu. Jako funkcionář svazu jsem byl pouhým začátečníkem, Jiránek jako muž významných funkcí a úřadů brojil na zasedání v Bratislavě proti přijetí mého návrhu. Argumentoval přitom slovy, že bychom se pak mohli dočkat přijetí podobné komise ze svazové odbočky v Ústí nad Labem. Osvícení členové hudebně vědné sekce svazu a solidární slovenští kolegové se za můj návrh postavili, a tím byla celá otázka ku prospěchu věci vyřešena. Zastoupení brněnské komise hudební vědy v hudebně vědecké sekci skladatelského svazu prospělo jednání v některých klíčových otázkách české hudební vědy, zejména kongresu na Mezinárodním festivalu Leoš Janáček a soudobá hudba. ${ }^{3}$ Budiž však řečeno, že týž Jaroslav Jiránek časem změnil svůj názor na Helferta, že se rád zúčastňoval v době „normalizace“ brněnských mezinárodních hudebně vědných kolokvií, na nichž vystupoval s Jaroslavem Volkem, napřríklad jako oponent „idealistické estetiky“ Carla Dahlhause z Technické univerzity Západního Berlína.

Redaktor sborníku z konference roku 1986 Rudolf Pečman k mému dopisu uvádí, že připravuji o Helfertovi monografii. Ve skutečnosti jsem však z titulu vedoucího Ústavu hudební vědy pouze vypracoval projekt sebraných spisů Vladimíra Helferta, jak si to přál i Zdeněk Nejedlý. Informoval jsem o projektu i paní Blaženu Helfertovou. Zadal jeho úplné znění nakladatelství Editio Supraphon. To jej změnilo na Vybrané studie I. O hudeb-

1 PEČMAN, Rudolf (ed.). Vladimír Helfert v českém a evropském kontextu. Hudebněvědná konference $k$ 100. výročí narozeni pokrokového vědce a člověka, Brno 27.-28. února 1986. Brno: Svaz českých skladatelů a koncertních umělců, 1987.

2 HELFERT, Vladimír. Česká moderni hudba: studie o české hudebni tvořivosti. Olomouc: Index, 1936.

3 JIRÁNEK, Jaroslav - Karásek, Bohumil (eds.). Leoš Janáček a soudobá hudba: Mezinárodni hudebně vědecký kongres, Brno 1958. Praha: Panton, 1963. 
ni tvořivosti, z pověření redaktorky Mileny Černohorské jej vydal a úvodem opatřil František Hrabal. ${ }^{4} \mathrm{~K}$ vydání dalších svazků Helfertových vybraných spisů však již nedošlo, tento dluh vi̊či Helfertovu odkazu tak zůstává dodnes. V reflexích helfertián jsem nezapomněl na Jiř́iho Fukače. Jistě by prodléval mezi námi a jistě by na konferenci přednesl esteticko-teoretický příspěvek, jak bylo u jeho intelektu zvykem. Fukačovou, co do obsahu nejvýznamnější helfertiánou zůstala rozprava Helfert analytik z konference roku $1986 .{ }^{5}$ Živě k nám stále promlouvá. Pokusím se hlavní myšlenky Fukačovy rozpravy v největší stručnosti připomenout, a to nejenom z piety vůči jejímu autorovi, nýbrž pro věc samu: kterak Jiří Fukač pojednal o Helfertových mnohostranných kulturních aktivitách; kterak charakterizoval Helfertova hlavní dokončená i nedokončená díla - a hlavně - kterak Helfert pokročil ve vývoji své vědy metologicky za pozitivistický koncept historiografických a etnografických prací Otakara Hostinského, za hermeneutiku skladatelských monografií Zdeňka Nejedlého.

Základem, z něhož vyrůstá hudební dílo, je podle Vladimíra Helferta inspirace. Vztahuje ji na umělcovu osobnost a prostředí, v němž žije. Je vyjádřena tvưrčím subjektem staticky ve vnitřní zákonitosti kompozičních znaků hudební struktury, nad níž stojí hudební výraz. Výraz jako paradigma funguje v dialektice s jejím syntagmatem, je produktem hudební tvořivosti vyjádřené skladatelským subjektem v hudební imanenci artefaktu. Struktura hudebního díla není schopna hudebními prostředky sdělit cokoliv z umělcovy ideologie, je dokumentem hudebního myšlení toho nebo onoho umělce nebo doby. Dějiny hudby jsou podle Helferta dějiny hudebního myšlení. Na míře výrazu závisí i míra uměleckosti hudebního díla.

Helfert, a zde už se zase vracím k Fukačovi, jako jeden z prvních muzikologů u nás a snad i v Evropě, pochopil, že analýza jednotlivého syntagmatu musí jít ruku v ruce s teoreticko-analytickou koncepcí odpovídajícího paradigmatu. Tam, kde jeho zkušenost i praktická analytická empirie stála zpochopitelných důvodů na méně zažitých základech, vidění této dialektiky ochabuje.

Pod Helfertův pojem dějin hudby jako dějin hudebního myšlení se nedají zařadit všechny hudební artefakty, které vznikaly v tisíciletí dějin i na naší půdě. Helfert rozebírá v první části České moderni hudby, v kapitole Česká hudebni tvořivost před Smetanou do maximálních detailů hudební strukturu (formu) Míčovy hudby, stejně jako v historiografické bilogii Jaroměřic. ${ }^{6}$ Míča zůstává podle Helferta na primitivní hudební kvadratuře. Účel jeho skladeb není přímo umělecký, Míča jako skladatel a úředník plní příkazy svého pána. Obsah Míčovy hudby se nezakládá na diferencovaném výrazu. Její hudební struktura zůstává v rovině raně klasického stylu podle učení Guido Adlera, kterého Helfert studoval. Předklasický hudební styl Míčových skladeb považuje Helfert za předstupeň

4 HELFERT, Vladimír. Vybrané studie. 1, O hudebni tvořivosti. Praha: Supraphon, 1970.

5 FUKAČ, Jiří. Helfert analytik. In PEČMAN, Rudolf (ed.). Vladimír Helfert v českém a evropském kontextu. Hudebněvědná konference $k$ 100. výroči narozeni pokrokového vědce a člověka, Brno 27. - 28. února 1986. Brno: Svaz českých skladatelů a koncertních umělců, 1987, s. 20-23.

6 HELFERT, Vladimír. Hudebni barok na českých zámcích: Jaroměřice za hraběte Jana Adama z Questenberku. V Praze: nákladem České akademie císaře Františka Josefa pro vědy, slovesnost a umění, 1916; HELFERT, Vladimír. Hudba na Jaroměřickém zámku: František Miča 1696-1745. V Praze: Česká akademie věd a umění, 1924. 
další etapy, kterou označuje za český hudební klasicismus. Ve výkladu se střetává v některých bodech s Erichem Steinhardem; především ve známém sporu o původcích mannheimské školy, jejíž symfonie znamenají oproti Míčovi progresi. Nabízí se otázka, nakolik se na tomto vývoji podílí i hudební výraz skladatele. Vývoj pokračuje u skladatelů další etapy, kterou Helfert označuje jako „českou hudebni tvořivost před Smetanou“. Ze skladatelů na domácí půdě ji zastupují Jan Václav Tomášek a Jan Václav Hugo Voříšek. Helfert shledává v jejich hudbě postup k výrazu, který se váže na hudební strukturu. Dialektika obou hudebních fenomenů funguje v hudebním díle dokonale. Helfert označuje Tomáška a Voříška za přímé Smetanovy předchůdce, z hlediska hudebního stylu pak za předchůdce hudebního romantismu na české půdě.

Progrese české hudby jako dějin hudebního myšlení pokračuje dál v moderní hudbě generace Smetanovy, kterou se její mluvčí Otakar Hostinský vzpíral označit termínem „romantický“, a přidává tak ke střechovému pojmu „moderní hudba“ pro celé dlouhé údobí atribut národní. V době vzniku novodobého českého národa neztrácí tato hudba obrodnou funkci, s jistým opožděním i v hudbě na Moravě. Atribut „moderní“ poukazuje na vazby této zejména Smetanovy a Fibichovy hudby s revolučními romantiky Berliozem, Wagnerem a Lisztem, v Dvořákově hudbě na první neoklasicismus Brahmse, propojený se zvláštním druhem osobní zaujatosti.

Helfert pokračuje ve výkladu české moderní hudby v etapách, které nazve Na přelomu romantismu a Cesty za novým stylem. Časově se za první třetinu 20. století již nedostane. V názvu spisu Česká moderni hudba mizí atribut národní, který nemá již původní obrodný smysl a význam. Jednotící silou progrese je pojem „hudební modernismus“, pod nějž se dostane svým podílem řada významných skladatelských subjektů. Osovou osobností je podle Helferta Vítězslav Novák. Mistr vytvořil svůj nový typ melodie i harmonie, skladby v bohatství žánrů a forem evropské umělé hudby. Novákovy skladby jsou ve vnitřním organismu konsistentní, naplňuje je subjektivní výraz. Dialektika paradigmat a syntagmatu v nich ochabuje jen ojediněle.

Leoš Janáček se u Helferta poněkud překvapive nalézá mezi skladateli 19. století, jako pokračovatel Pavla Kř́žzovského. Následně je řazen za romantika Jána Levoslava Bellu jako představitel hudebního realismu. Janáček je protipólem Smetanovým, s nímž zůstal zajedno pouze v opeře Šárka. Janáčkova jednoaktovka Počátek románu znamená krátké vybočení z nastoupené hudební cesty, za jejíž nový začátek v definitivním znění považuje Helfert Jeji pastorkyni. V opeře vidí hlavní oblast vývoje Janáčkova hudebního stylu. Připouští, že se Janáček obrátil po převážně lyrických inspiracích v operách Kát’a Kabanová a Př́hody lišky Bystroušky k nejtvrdšímu, prudkému realismu (opery Věc Makropulos a $Z$ mrtvého domu). Helfert tak mohl vymezit hlavní znaky Janáčkova hudebního stylu, který kotví v moravském hudebním folkloru. Janáček ve struktuře skladby nedotvořuje hudební nápad, opatřuje ho melodickými a harmonickými změnami, v hudebním stylu stanul úplně mimo hudební kvadraturu. Důležitá je i Janáčkova práce se slovem. Janáčkovy nápěvky mluvy ovlivňují i jeho instrumentální myšlení, jehož znaky Helfert pozoruhodně analyzoval na Symfoniettě (1925). Janáček žene své motivy kupředu v prudkém dynamickém a agogickém proudu, tvrdí Helfert. V tom je Janáček jedinečný. Helfert Janáčka přesto všechno zařazuje mezi české skladatele 19. století. To, že se narodil o pouhé 
čtyři roky po Fibichovi, o ničem nevypovídá. Janáček žil a tvořil po léta v jednom časovém prostoru s Vítězslavem Novákem, který byl považován před první světovou válkou za hlavu moderní hudby na Moravě. V dvacátých letech žije Janáček v dotyku s moderními směry dvacátých let, čemuž Helfert nevěnuje již tolik pozornosti.

Vladimír Helfert brzy po příchodu do Brna překonává svou dřívější averzi vưči Janáčkovi. Nejmenuje ho ani mezi českými hudebními modernisty v podivuhodné programové rozpravě Naše hudba a český stát, kterou napsal krátce před vyhlášením československé samostatnosti. ${ }^{7}$ Při neujasněnosti kulturních a politických poměrů na Slovensku a v české části Slezska, uvažuje o Brnu jako o druhém hlavním městu východní části rodící se republiky. Ke třesku v Helfertově vztahu k Janáčkovi dochází až někdy kolem jeho jmenování doctorem honoris causa Masarykovy univerzity roku 1925. Janáček je nejvíce zastoupeným skladatelem v Helfertově hudební publicistice. Jeho malá janáčkiána uveřejnil ve zvláštním svazku Bohumír Štědroň. ${ }^{8}$ Někdy od poloviny třicátých let vzniká při Helfertově neuvěřitelné veřejné a politické angažovanosti vícesvazkový projekt janáčkovské monografie, ${ }^{9}$ jejíž první díl dokončil a uveřejnil krátce před svým uvězněním německými nacisty.

Vladimír Helfert byl vědecky i morálně oprávněn k tomu, aby vytvořil o Leoši Janáčkovi velkou vícesvazkovou monografii. Helfertovo dvojí zatčení za Protektorátu mu to znemožnilo. Redakce nakladatelství Panton mě pak pověřila, abych sestavil a vedl tým, který by Helfertův projekt Janáčka roku 1939 „dokončil“. Uvědomoval jsem si náročnost tohoto úkolu. Vypracoval jsem návrh na jeho realizaci a rozdělil kompetence na jednotlivé svazky jednotlivcům. Na poradách týmu jsme postupovali kolektivně, do řešení některých esteticko-teoretických otázek jsme zapojili na konferencích Janáčkovy společnosti externisty. $\mathrm{V}$ analytických částech monografie měly být hlavním vodítkem Helfertovy menší studie a Česká moderni hudba.

Práci na monografii jsem zahájil na základě nových pramenných rešerší revizí první části Helfertova textu. Vypracoval jsem zásady na napsání (dokončení) ostatních svazků, které jsem otiskl v časopisu Hudebni věda. ${ }^{10}$ Vše se však vyvíjelo po sametové revoluci ve skutečnosti jinak. Členové týmu rezignovali na spolupráci a rozhodli se pro individuální úkoly. Hlásím se ke spoluzodpovědnosti za nedokončenost „Helfertova Janáčka“, který zůstal v podobě, jak ho zamýšlel a napsal jeho původce.

Janáčkovská monografie neměla být jediným dílem, které by Vladimír Helfert dokončil, až by se vrátil domů po osvobození z nacistických káznic. Pomýšlel i na napsání na dalších děl. Dočteme se o tom v Hovorech tužkou, ${ }^{11}$ které mohl napsat za přispění svého dělnického spoluvězně Jury Sosnara, statečného zachránce Helfertova rukopisu.

7 HELFERT, Vladimír. Naše hudba a český stát. V Praze: B. Kočí, 1918.

8 HELFERT, Vladimír. O Janáckovi: soubor statí a článků: práce ze Semináre hudebni výchovy na Masarykově universitě v Brně. Praha: Hudební matice Umělecké besedy, 1949.

9 HELFERT, Vladimír. Leoš Janáček: obraz životního a umèleckého boje. 1, V poutech tradice. Brno: nákladem Oldřicha Pazdírka, 1939.

10 VYSLOUŽIL, Jiř́i. Návrh na monografii Leoš Janáček, život a dílo. Hudební věda, 1995, č. 2, s. 138-143.

11 HELFERT, Vladimír a Jura SOSNAR. Hovory tužkou: dokumenty z let 1941-42. Praha: Svaz československých skladatelů, 1956. 
Vydání Hovorů po konzultaci s Helfertovou chotí Blaženou je dílem Jana Racka a Ivana Vojtěcha. Jsou písemným svědectvím Helfertovy statečnosti a morální síly za jeho věznění v nacistických káznicích. Pojednávají o věcech politických, uměleckých a filosofických. Helfert v nich načrtává do podrobností program své budoucí práce, které se mínil po osvobození věnovat. V politických úvahách pokračoval v kritice Wilsonovy obrozenské doktríny národi̊, na stránkách České moderni hudby shledával její nedostatek v řešení sociální otázky. S kritikou kapitalismu začal již v úvaze Naše hudba a český stát.

$\mathrm{V}$ polovině třicátých let se ocitl ve skupině levicových a komunistických intelektuálů olomoucké kulturní revue Index. Pod vlivem literárního kritika Bedřicha Václavka, filosofa Josefa Ludvíka Fischera a jiných uvěřil, že náprava poměrů přijde z nového Ruska, v němž roste po revoluci nový svět, naplněný úžasnou vírou v pracujícího člověka. V této víře se utvrdil v rozmluvách s Jurou Sosnarem za věznění v nacistických káznicích ve Vratislavi a Wohlau. Rozmlouvali společně o komunismu jako o nové vyšší fázi socialismu. Helfert však nikdy komunistou jako člen strany nebyl, jak to uvádí nepodloženě publikace o dějinách Filozofické fakulty Masarykovy univerzity. ${ }^{12}$ Jako stoupenci této ideje mu nebyly známy zločiny, jichž se dopustil stalinský režim na vlastním lidu, na kultuře, umění a vědě.

Můžeme si klást otázku, jak by se Vladimír Helfert choval a co by ho čekalo, kdyby se dožil roku 1945 a posléze komunistického puče v únoru 1948 s jeho neostalinskými politickými praktikami. Kvůli zásadovosti a morální bezúhonnosti by ho v nejmenším čekal stejný osud jako profesora sociologie Arnošta Inocence Bláhu, který musel roku 1948 z fakulty odejít. Nebo by ho, jako některé jiné vědce, čekaly mnohem horší postihy. Je bolestné a smutné na to pomyslet.

\section{Bibliography}

FASORA, Lukáš a Jiří HANUŠ. Filozofická fakulta Masarykovy univerzity: pohledy na dějiny a současnost. Brno: Masarykova univerzita, 2010.

FUKAČ, Jiří. Helfert analytik. In PEČMAN, Rudolf (ed.). Vladimír Helfert v českém a evropském kontextu. Hudebněvědná konference k 100. výročí narození pokrokového vědce a člověka, Brno 27.-28. února 1986. Brno: Svaz českých skladatelů a koncertních umělců, 1987, s. 20-23.

HELFERT, Vladimír a Jura SOSNAR. Hovory tužkou: dokumenty z let 1941-42. Praha: Svaz československých skladatelů, 1956.

HELFERT, Vladimír. Česká moderní hudba: studie o české hudební tvořivosti. Olomouc: Index, 1936.

HELFERT, Vladimír. Hudba na Jaroměřickém zámku: František Míča 1696-1745. V Praze: Česká akademie věd a umění, 1924.

HELFERT, Vladimír. Hudební barok na českých zámcích: Jaroměřice za hraběte Jana Adama z Questenberku. V Praze: nákladem České akademie císaře Františka Josefa pro vědy, slovesnost a umění, 1916.

12 FASORA, Lukáš a Jiří HANUŠ. Filozofická fakulta Masarykovy univerzity: pohledy na dějiny a současnost. Brno: Masarykova univerzita, 2010. 
HELFERT, Vladimír. Leoš Janáček: obraz životního a uměleckého boje. 1, V poutech tradice. Brno: nákladem Oldřicha Pazdírka, 1939.

HELFERT, Vladimír. Naše hudba a český stát. V Praze: B. Kočí, 1918.

HELFERT, Vladimír. O Janáčkovi: soubor statí a článků: práce ze Semináře hudební výchovy na Masarykově universitě v Brně. Praha: Hudební matice Umělecké besedy, 1949.

HELFERT, Vladimír. Vybrané studie. 1, O hudební tvořivosti. Praha: Supraphon, 1970.

JIRÁNEK, Jaroslav - Karásek, Bohumil (eds.). Leoš Janáček a soudobá hudba: Mezinárodní hudebně vědecký kongres, Brno 1958. Praha: Panton, 1963.

PEČMAN, Rudolf (ed.). Vladimír Helfert v českém a evropském kontextu. Hudebněvědná konference k 100. výročí narození pokrokového vědce a člověka, Brno 27.-28. února 1986. Brno: Svaz českých skladatelů a koncertních umělců, 1987.

VYSLOUŽIL, Jiří. Návrh na monografii Leoš Janáček, život a dílo. Hudební věda, 1995, č. 2, s. $138-143$. 
